\title{
Global expansion of quinoa and challenges for the Andean region
}

\author{
G. Alandia ${ }^{\text {a, }}$, J.P. Rodriguez ${ }^{\text {b }}$, S.-E. Jacobsen ${ }^{\text {c }}$, D. Bazile ${ }^{\text {d,e }}$, B. Condori ${ }^{f}$ \\ ${ }^{a}$ University of Copenhagen, Faculty of Science, Department of Plant and Environmental Sciences, Hojbakkegaard Alle 13, DK-2630, Taastrup, Denmark \\ ${ }^{\mathrm{b}}$ Crop Diversification and Genetics Program, International Center for Biosaline Agriculture, ICBA, Dubai, P.O. Box 14660, United Arab Emirates \\ c Quinoa Quality Aps, DK-4420, Regstrup, Denmark \\ d UPR GREEN, CIRAD, 34398 Montpellier, France \\ e GREEN, Univ Montpellier, CIRAD, Montpellier, France \\ ${ }^{\mathrm{f}}$ Inter-American Institute for Cooperation on Agriculture. Bolivian Representation - IICA, La Paz, Bolivia
}

\section{A R T I C L E I N F O}

\section{Keywords:}

Chenopodium

Market

Agrobiodiversity

Sustainability

Diversification

Food security

\begin{abstract}
A B S T R A C T
Quinoa (Chenopodium quinoa, Willd.) is an Andean grain crop recognized as an ally for global food security due to its high nutritional value. However, quinoa globalization entails challenges to the countries of origin. Farmers face a scenario of new concerns and competitors. In 2018, quinoa was present for research and production in 123 countries. Although 74\% of global exports are still supplied by Peru and Bolivia, production outside the Andes is increasing. In addition, producer prices collapsed in 2015 while yields remained unstable, averaging $0.4-1.1 \mathrm{t}$ $\mathrm{ha}^{-1}$. Understanding the reality of the new quinoa situation is fundamental to face the challenges of encouraging local biodiversity, promoting market diversification and cooperating with inclusive processes towards equitable benefits.
\end{abstract}

\section{Introduction}

Quinoa (Chenopodium quinoa, Wild.) is a dicotyledonous, $\mathrm{C}_{3}$ species from the Amaranthaceae family that produces achene fruits (chenopod grains) with a rounded seed of 1.5-4 mm (Gallardo et al., 1997; Jellen, 2013; Garcia et al., 2015). It can grow under diverse agro-ecological zones (coastal, valley, highlands, salt flats and subtropic) and is tolerant to frost, salinity and drought (Jensen et al., 2000; Jacobsen et al., 2005; Adolf et al., 2013; Tapia, 2014).

The dry quinoa seed is consumed as a cereal grain and has gained importance globally due to its high nutritional value. The balance of essential amino acids, fatty acids, micronutrients, vitamins and antioxidants is considered of high quality compared to the principal cereals (Ruales and Nair, 1992; Repo-Carrasco et al., 2003; Tapia et al., 1979; James, 2009). As a gluten free food grain with a low Glycemic Index, quinoa is a viable alternative for special diets and industries (Gordillo-Bastidas et al., 2016).

The resilience and the high nutritional quality distinguish quinoa as a potential strategic crop for food security and nutrition (Rojas et al., 2011; FAO, 2011; FAO and Bioversity International, 2012).

Part of quinoa's history and evolution at the global level has been summarized (Alandia et al., 2011b; Bazile and Baudron, 2014; Bazile et al., 2016a). However, the link between different factors is still necessary in order to show the resulting challenges for the region of origin, i.e. the Andean region. In this paper, we update information published by Bazile et al. (2016a) with new data. Our objective is to analyze the main drivers of quinoa evolution, reveal important implications and challenges farmers confront, to suggest possible solutions.

\section{Methods}

We have focused on Peru, Bolivia and Ecuador as representative countries producing quinoa in the Andean region for the following reasons: these Andean countries hold the largest quinoa cropping areas and they constitute important areas of domestication and biodiversity.

This analysis considered various databases and information sources to develop visual representations for interpretation. To describe the dynamics in the studied region we used information on quinoa production areas, volumes, yields, export and prices from official national databases, local ministries, quinoa associations and statistic and export offices in each country (Bolivia: National Statistics Institute, Todo sobre la quinua; Peru: Ministry of Agriculture and Irrigation; Ecuador: Ministry of Agriculture and Husbandry). International databases used are from the FAO, the International Trade Centre, Eurostat and CBI Market

\footnotetext{
* Corresponding author.

E-mail addresses: gar@plen.ku.dk (G. Alandia), j.calle@biosaline.org.ae (J.P. Rodriguez), quinoa@paradis.dk (S.-E. Jacobsen), didier.bazile@cirad.fr (D. Bazile), bcondori@yahoo.com (B. Condori).
} 


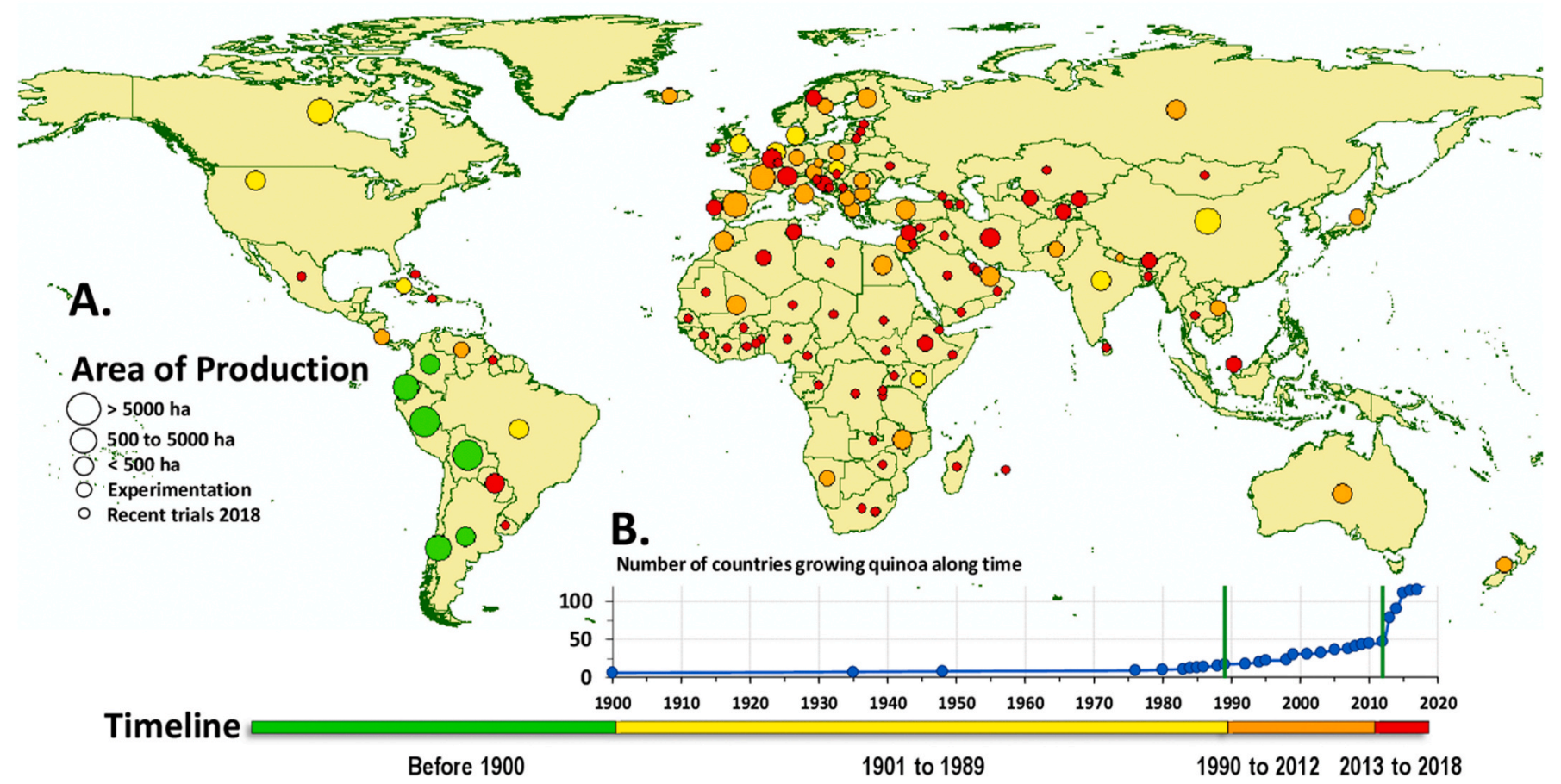

Fig. 1. Global distribution of quinoa along time: (A) areas of production and experimentation with quinoa and (B) number of countries growing quinoa.

Information. Using ArcGIS version 10 (ESRI, 2011) and applying an updated database from Bazile et al. (2016a) (gathered in 2019 with the latest data up to 2018), we generated a world distribution map considering a timescale and production areas. We defined a timescale with four distinct periods: a) before the 1900s, to indicate the traditional producing countries; b) between 1901 and 1989, to show the first seed flow outside the Andean region; c) between 1990 and 2012, to visualize the distribution of quinoa as a result of projects and research; and d) between 2013 and 2018, to locate the most recent experimentation. Five categories to show the status of quinoa presence were considered: major producers ( $>5000$ ha under quinoa cultivation); medium producers (500-5000 ha under quinoa cultivation); small producers $(<500$ ha under quinoa cultivation); experimentation without production; and most recent trials (2013-2018).

\section{Results and discussion}

\subsection{Quinoa dynamics inside and outside the Andean region}

Figure 1 illustrates the distribution and status of quinoa along time and Table 1 provides related numerical data.

\subsubsection{Before the 1900s}

Figure 1 shows with green the main region of origin, domestication and production of quinoa. Quinoa resulted from hybridization between two diploid species (probably 3.3-6.3 million years ago) and domestication took place at least $3000 \mathrm{BC}$ independently in coastal and highland environments (Bruno, 2006; Planella et al., 2014; Jarvis et al., 2017).

Mainly six countries along parallels $5^{\circ}-42^{\circ}$ south latitude (covering Colombia, Ecuador, Peru, Bolivia, Argentina and Chile), cultivated quinoa as an important component of their diet (Tapia et al., 1979; Fleming and Galwey, 1995; Maughan et al., 2007). During the Hispanic period, quinoa was reported as a local food crop in chronicles and communications to the crown. The first attempt to test this grain outside the Andes failed in Spain due to non-viable seeds (Gonzáles et al., 2015). This Andean grain was probably not introduced to Europe as were potatoes and maize, due to laborious post-harvesting process and the presence of saponins (Keoke and Porterfield, 2009). In the 1800s, there were suggestions to introduce quinoa to the Russian empire, though, with not proven materialization (Baer, 1839; Loskutov, 1999). Andean countries kept producing quinoa as small, medium and major producers (Table 1). By 2018, Peru and Bolivia were the two major world producers with an area of 58,000 and 111,000 ha, respectively (Fig. 2).

\subsubsection{1-1989}

During the 20th century, quinoa seed was brought to Africa, North America, Europe and Asia (marked with yellow in Fig. 1). Initial experimentation is reported in the African continent in 1935 (Oyoo et al., 2014; Bazile and Baudron, 2014) and in the 1970s and 1980s in the northern continents (North America and Europe). The first commercial

Table 1

Quinoa worldwide presence along time and status by 2018.

\begin{tabular}{|c|c|c|c|c|c|c|c|c|c|c|c|}
\hline \multirow[b]{2}{*}{ Time period } & \multicolumn{5}{|c|}{ Number of countries by continents along time } & \multicolumn{5}{|c|}{ Status of countries by 2018} & \multirow[b]{2}{*}{ Total } \\
\hline & America & Europe & Asia & Africa & Oceania & 1 & 2 & 3 & 4 & 5 & \\
\hline Before 1900 & 6 & 0 & 0 & 0 & 0 & 0 & 0 & 2 & 2 & 2 & 6 \\
\hline 1901-1989 & 4 & 4 & 2 & 1 & 0 & 1 & 2 & 6 & 2 & 0 & 11 \\
\hline 1990-2012 & 2 & 14 & 7 & 5 & 2 & 3 & 14 & 11 & 2 & 0 & 30 \\
\hline 2013-2018 & 6 & 15 & 24 & 31 & 0 & 61 & 11 & 4 & 0 & 0 & 76 \\
\hline Total & 18 & 33 & 33 & 37 & 2 & 65 & 27 & 23 & 6 & 2 & 123 \\
\hline
\end{tabular}

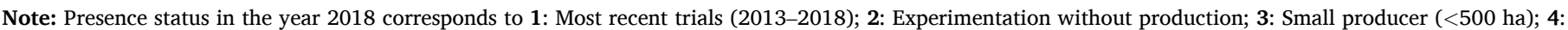
Medium producer (500-5000 ha); 5: Major producer ( $>5000 \mathrm{ha}$ ). 
a

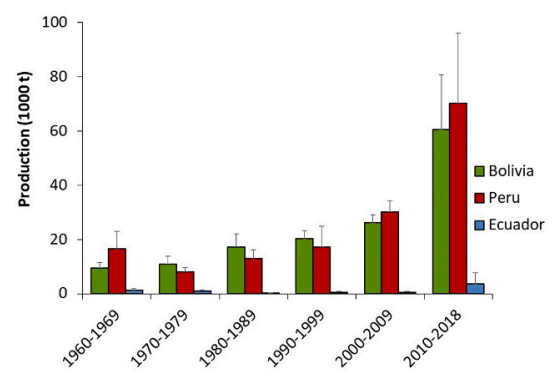

C

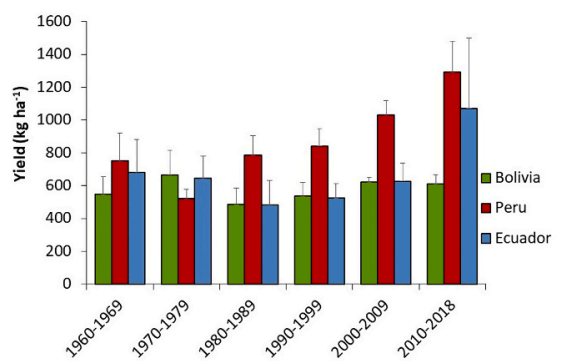

e

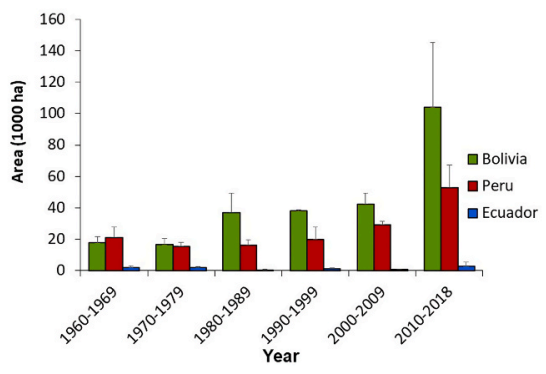

b

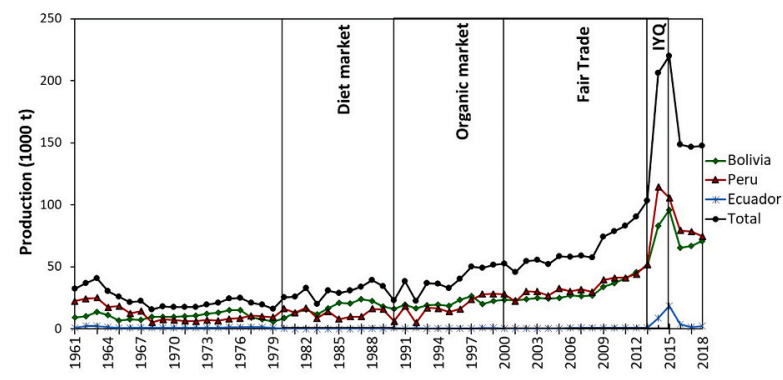

d

f

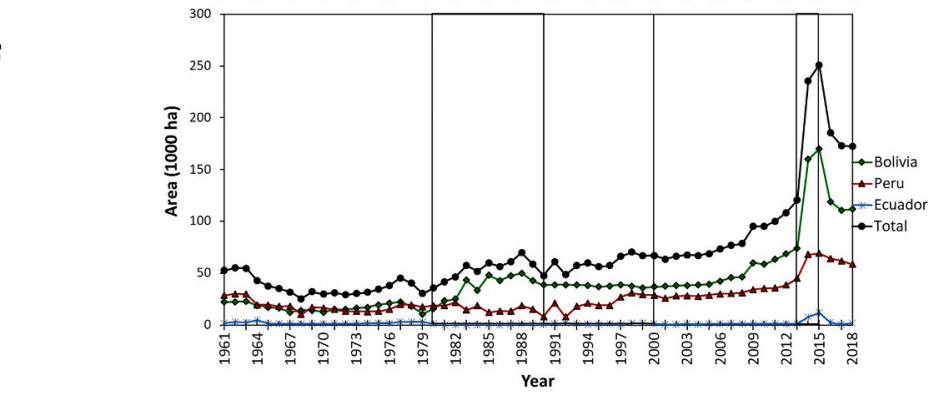

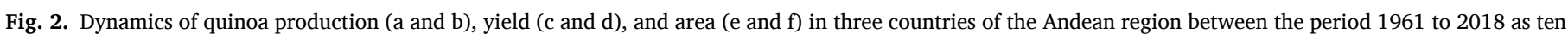

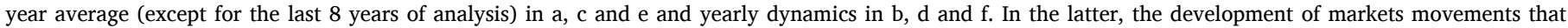

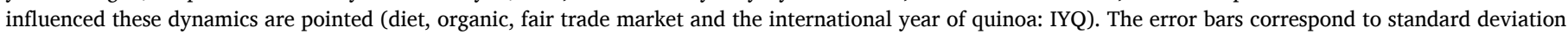
$(\mathrm{n} \pm 1)$.

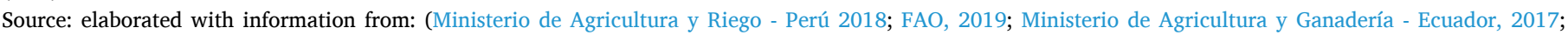
Instituto Nacional de Estadística, 2019; Ministerio de Agricultura y Ganadería - Ecuador, 2019).

cultivation outside the Andes was established in 1983 in Colorado (USA) together with a breeding program, a cultivar (Colorado 407) and farmer associations in the United States and Canada (Alandia et al., 2011b; Peterson and Murphy, 2014). In Europe, the first countries where quinoa was introduced for research were England, Denmark and the Netherlands (Risi and Galwey, 1984; Galwey, 1993; Jacobsen, 2003). During that period, quinoa was also tested in India, China (Bhargava and Ohri, 2014; Xiu-shi et al., 2019) and under lowland tropical conditions in Brazil (Spehar and de Souza 1993; Spehar et al., 1998).

By the end of the 1980s, quinoa was actively present for research and production in 11 countries outside the Andes. By 2018, six of these countries (United States, the Netherlands, Denmark, UK, India and Brazil) were reported as small producers with less than 500 ha and two (Canada and China) as medium producers (with areas between 500 5000 ha).

\subsection{3. $1990-2012$}

In the 1990s quinoa spread to 13 new countries, propelled by two international projects in 1993 and 1996 (Jacobsen, 2003; Bazile and Baudron, 2014). The Netherlands gave rise to the first European cultivar
"Carmen" (early short size compact plant) and the sweet variety "Atlas" (Jacobsen, 2003). The United States worked with male sterility and molecular markers to breed quinoa. They obtained tolerant varieties to early sprouting and successful crosses with other Chenopodium (Peterson and Murphy, 2014). By 2012, quinoa appeared in 17 more countries, this time in the Mediterranean region, Asia and Africa (Bazile and Baudron, 2014). In France, by 2011, a local quinoa sector reported 300 ha of production using two Dutch sweet varieties with yields ranging $2-4.5 \mathrm{t} \mathrm{ha}^{-1}$ for conventional and $0.8-2 \mathrm{t} \mathrm{ha}^{-1}$ for organic quinoa (Piva et al., 2014). By 2012, quinoa is present in 30 countries (marked with orange in Fig. 1). Two of them (Spain and France) became medium producers and 11 of those were small producers (including countries in Middle East desert and Oceania) as it is shown in Table 1.

\subsection{4. $2013-2018$}

After the International Year of Quinoa (IYQ), from 2013 to 2018, 76 countries tested and produced quinoa in different latitudes (red color in Fig. 1). Most of them were located in Africa (41\%), Asia (32\%) and Europe (20\%). By 2018, four countries (Belgium, Iran, Switzerland and Paraguay) were reported as medium producers (Table 1). 
a
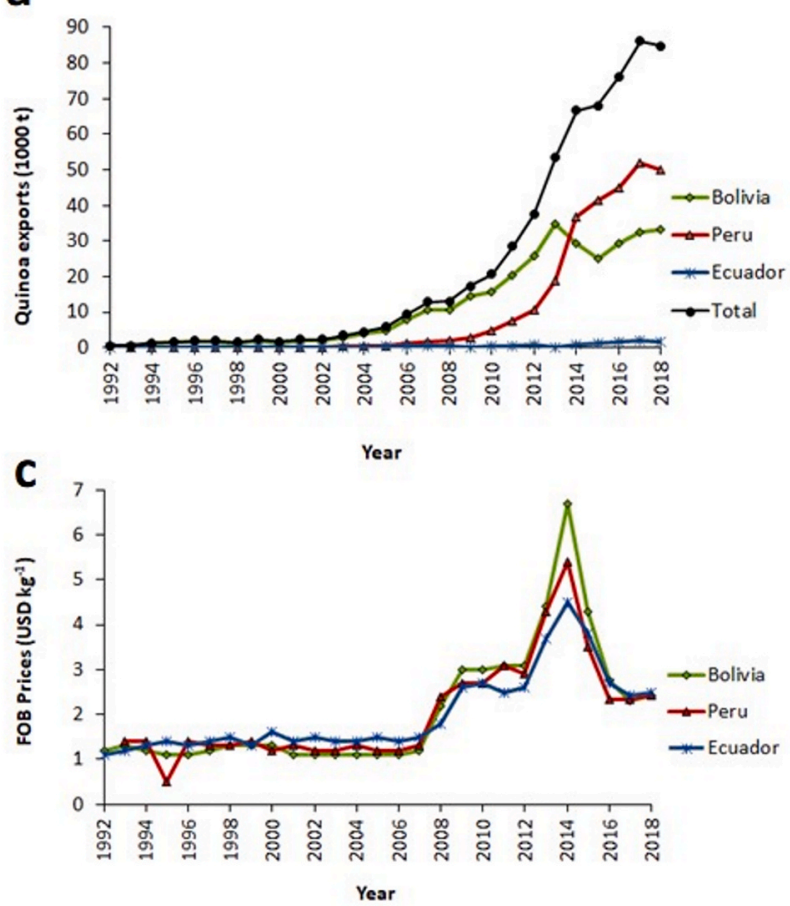

b
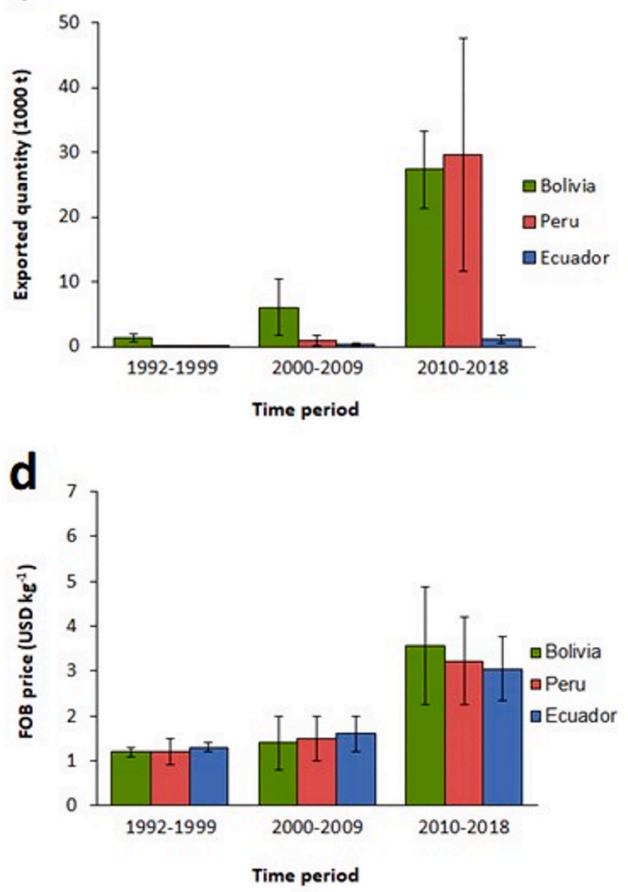

Fig. 3. Exported quinoa quantities (a, b), and FOB producer prices (c, d) from the Andean region. Error bars correspond to standard deviation (n \pm 1 ). Source: Elaborated with information from: (International Trade Centre, 2019).

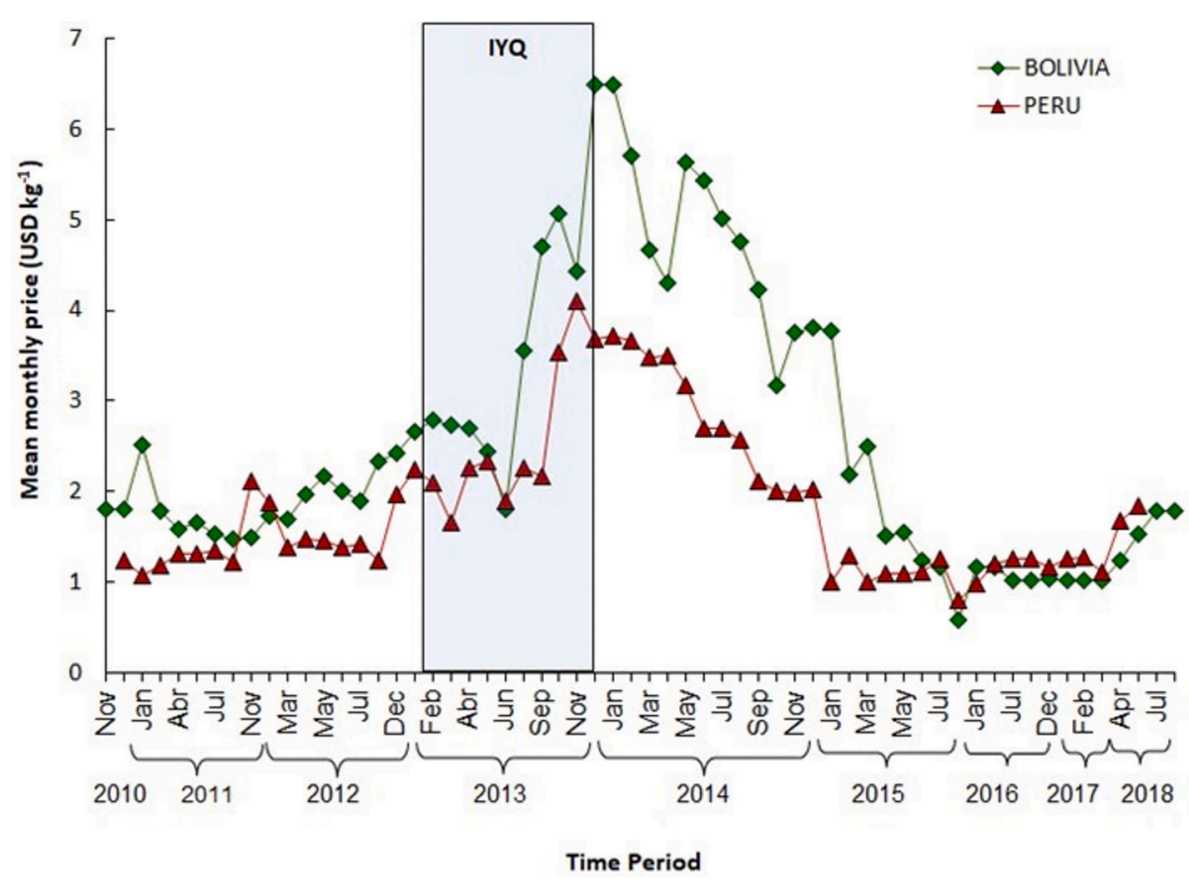

Fig. 4. Producer prices for conventional quinoa in Peru and Bolivia 2010)-2018 with highlighted variation during the International Year of Quinoa (IYQ). Source: elaborated with information from: (Todo sobre la Quinua, 2019; Ministerio de Agricultura y Riego - Ministerio de AgriculturaRiego - Perú, 2018).

\subsection{The main drivers of change: new markets, prices, research and promotion}

The rapid spread of this grain around the world can be attributed to the conjunction of different elements along time, which are discussed in this section.

\subsubsection{New markets and prices}

Figure 2 shows the decade and annual evolution of quinoa production volumes, yields and areas between 1960 and 2018 for the three analyzed countries.

In the 1960s and 1970s, quinoa production in the Andean region was addressed for the local market. The majority (95\%) of production 
volumes and production area were concentrated and similarly distributed between Peru and Bolivia (Fig. 2a and e). In total for the three countries, the production ranged from 15,600 - 40,800 $\mathrm{t}$ (Fig. 2b), in areas between $25,100-55,000$ ha (Fig. 2f). Yields were variable and below $0,8 \mathrm{t} \mathrm{ha}^{-1}$ (Fig. 2d).

Emerging consumption preferences and trends in developed countries gave rise to new markets that created a demand for quinoa i.e. diet, organic and fair trade (Vassas and Vieira P, 2010).

Quinoa was first introduced to the North American food market in the 1980s, when a diet market started to develop, and different companies started to import this novel grain from Bolivia, Peru and Ecuador. The area of production in the Andean region increased from 35,500 ha in 1980 to 58,700 ha in 1989 (Fig. 2-f) of which 73\% was located in Bolivia (42,600 ha by 1989). National policies in this country (neo-liberalism), the creation of quinoa associations, the mechanization of production practices were some of the factors that transformed subsistence production to commercial production for export (Alandia et al., 2011a; Laguna, 2011).

In the 1990s, the rapid development of the organic food industry included quinoa, new interests emerged for whole grains and Andean countries improved their grain cleaning capacities. Fair trade developed and by the end of the 2000s, quinoa had become a specialty food product in the US (Laguna et al., 2006; Núñez de Arco, 2015). Export demand and prices were the main drivers of change for the production area in the Andean region. For almost two decades (1990-2007), quinoa prices remained below $2 \mathrm{USD} \mathrm{kg}^{-1}$ (Fig. $3 \mathrm{c}$-d). Quinoa FOB prices increased from $1.3 \mathrm{USD} \mathrm{kg}^{-1}$ in 1999 to $2.8 \mathrm{USD} \mathrm{kg}^{-1}$ in 2010 (Fig. 3c). Exports were boosted; by 1999, the region exported more than $2000 \mathrm{t}$ whereas by 2010 , exports increased by ten $(20,600 \mathrm{t})$ (Fig. 3a). Hence, the production area increased from almost 67,000 ha in 1999 to 95,000 ha in 2010 (Fig. 2). Prices started to increase by the end of the 2000 s due to different reasons along this period: stronger demand from the US; a higher demand in relation to supply; the need to ensure the supply chain when importers faced contract defaults; and speculation during the IYQ (Avitabile, 2015; Núñez de Arco, 2015). Prices in Bolivia reached the highest values by the end of 2013 (6.7 USD kg ${ }^{-1}$ FOB price in Fig. 3-c; and $6.5 \mathrm{USD} \mathrm{kg}^{-1}$ farmers price in Fig. 4). Prices for organic quinoa were even higher; by December 2013 they reached $8 \mathrm{USD} \mathrm{kg}^{-1}$ for Bolivia and $7 \mathrm{USD} \mathrm{kg}^{-1}$ for Peru (Núñez de Arco, 2015). These prices led in 2015 to the highest peak in production area (251,000 ha) and volumes $(220,000$ t) registered in the region along the last decade (Fig. $2 \mathrm{f}$ and b). In only two years (from 2013 to 2015), the production area more than doubled in Bolivia and increased by almost ten times in Ecuador. For two decades (1992-2013), Bolivia was the main exporter and covered $65-95 \%$ of exports from the Andean region. In fact, it is this country that positioned quinoa in the global market (Laguna, 2011). In 2014, after the IYQ, Peru took over with the exports (Fig. 3b).

Quinoa prices collapsed in 2014. In that year, the Andean region produced 206,000 t (Fig. 2-b) and exported 66,000 t (Fig. 3-a). Producing a higher quantity than the Andean countries exported led to the downward correction of quinoa prices to $2.5 \mathrm{USD} \mathrm{kg}^{-1}$ (FOB price, Fig. 3-c) and $1.8 \mathrm{USD} \mathrm{kg}^{-1}$ (farmers price, Fig. 4) by the end of 2018. The production area in the Andean region lowered to 172,000 ha and the production volumes to $147,500 \mathrm{t}$. In that year (2018), Peru and Bolivia exported more than $84,000 \mathrm{t}$ (Fig. 3a) equivalent to $74 \%$ of global quinoa exports. However, some markets closed and four countries outside this region i.e. United States, Canada, Spain and the Netherlands competed with $16 \%$ of world's exports (CBI Market Information Database, 2017). The effect of the price collapse, closing markets and new competitors had a strong impact for small farmers in Bolivia and Peru who faced prices as low as $0.6 \mathrm{USD} \mathrm{kg}^{-1}$ and $0.8 \mathrm{USD} \mathrm{kg}^{-1}$ respectively by the end of 2015 (Fig. 4).

Nowadays novel markets continue to emerge in developed countries. Environmentally responsible consumers (e.g. vegan, vegetarians, flexitarians) are generating demand for plant based food, where quinoa plays an important role as a high-quality protein grain.

\subsubsection{Research and promotion}

\section{a) In the Andean region}

Important research in quinoa has taken place within the Andean region. The description and generation of scientific information about quinoa between the 1960s and 1980s comprised collection, description, characterization and conservation of local germplasm; plant breeding; plant protection and general crop production; nutrition; uses, processing and industry (Tapia, 2014; Zandstra, 1997; Tapia et al., 1979). Agricultural research and development in the south had variable intensity and stability, typical of the dynamics of governments and politics in Latin American countries. Not all of the research generated reached farmers but it certainly established the basis for subsequent research into quinoa, not only in the region but also around the world (Rea, 1992; Zandstra, 1997; Laguna et al., 2006). For long time (up to the 2000), average yields for the region remained around $0.6 \mathrm{tha}^{-}{ }^{1}$. From the three countries analyzed, Peru had the highest annual yield averages and Bolivia the lowest, due to its harsher highland climatic conditions (Fig. 2-d). A great effort in plant breeding has been done in the Andean countries. Nevertheless, the resulting cultivars are not as protected or disseminated for experimentation as other genetic materials are in the rest of the world.

Recent studies include the generation and release of cultivars (e.g. the first cultivar registered by Chile in 2001); generation of bio-inputs; integration of native vegetation in cropping systems; ethno-socioeconomic studies describing related dynamics and the quinoa production chain, among others (Tapia, 2014; Gandarillas et al., 2014; Peralta and Mazón, 2014; Planella et al., 2014). It is indeed after the 2000s that the region increases the yield average especially with Peru that reached more than $1 \mathrm{t} \mathrm{ha}^{-1}$ after 2002 and Ecuador after 2014. Bolivia kept with $0.6 \mathrm{t} \mathrm{ha}^{-1}$ during this period (Fig. 2-d).

\section{b) Outside the Andean region}

The start of quinoa exports and consumer's interests outside the Andean region, gave rise to germplasm collections and experimentation with this grain outside the Andes. Plant breeding outside the Andean region was mainly concentrated on high yielding, uniformity for mechanical harvesting, tolerance to sprouting, early maturation and low saponin in grain (Jacobsen, 2014; Bazile et al., 2016a; Peterson and Murphy, 2014). At the moment there are 26 registered quinoa cultivars, of which only three come from the Andean region (UPOV, 2019).

The recent genome sequencing of quinoa, fully achieved in 2017, may accelerate plant breeding with novel technologies, to obtain uniform commercial cultivars with targeted traits for quinoa production under a wider range of regions and stresses (Jarvis et al., 2017). New projects outside the Andean region are addressing breeding: in the United States, to generate high yielding varieties that are tolerant to biotic and abiotic stresses under organic farming systems (USDA - ARS, 2019); in Europe, to obtain varieties that adapt to long days and short summers (Kiel University, 2018) and for reduced saponin in the seed coat through non-gmo mutagenesis technology (The Carlsberg Foundation, 2019; López-Marqués et al., 2020). These new breeding technologies and capabilities are unfortunately lacking in the Andean region, although they are important in order to increase crop productivity (Tester and Langridge, 2010). Other European projects have considered quinoa as part of an array of protein crops targeted to develop new plant based food products that contribute to reduce greenhouse gas emissions and negative impacts on the environment (European Commission, 2017). Nowadays, China is making important investments in research to develop quinoa. In 2018, 12,000 ha were sown mainly in the northern part of the country (Xiu-shi et al., 2019).

Numerous research projects were developed outside the Andean region, but those in the 1990s and right after the International Year of Quinoa (IYQ) in 2013 might be the ones that had the most impact in the 
dispersal of this grain (Bazile et al., 2016a; Bazile et al., 2016b). The IYQ helped to spread quinoa around the globe and increased demand, production area, volume and exports as shown in Figs. 1-3. This took place in around 30 countries through more than 70 events. The use of mainstream media to promote and disseminate material also magnified the visibility of this grain (programs, special editions in magazines and newspapers, recipe books, among others) (FAO, 2013, FAO, 2014).

\subsection{Implications of quinoa globalization: sustainability and ethical use of genetic resources}

\subsubsection{Sustainability}

Sustainability has been a concern raised along with quinoa globalization (Vassas, A., 2008, Giuliani, A., 2012, Winkel et al., 2014; Bedoya-Perales et al., 2018a).

The sustainability of quinoa production systems started to be discussed in Bolivia in the late 2000s, reaching later the international arena through mainstream media and scientific publications (Astudillo and Aroni, 2012; Avitabile, 2015; Albert, 2017).

With different degrees of complexity, multiple authors warned and debated about the impacts of the quinoa boom. They addressed unsustainable quinoa production practices and aspects such as the negative impacts of land use change on soils, traditional production systems and agro-biodiversity. Valuable management practices were also recommended for degraded soils; such as the sustainable use of mechanical plowing, the integration and diversification of production systems to enrich soil with organic matter (from harvest residues, manure, compost, intercrop systems with wild and traditional legumes). Moreover, cutting instead of pulling out quinoa plants during manual harvest and the implementation of wind barriers were recommended. Preserving traditional production systems was also highlighted to bring out diversity and resilience in small-scale farming (Winkel et al., 2012; Jacobsen 2011, 2012; Bedoya-Perales et al. 2018a, 2018b; Aroni, 2008; Reynolds et al., 2008; Winkel, 2011; Winkel et al., 2014).

The quinoa boom led to an increase of the production area and generated pressure on natural resources from the Andes. The unsustainable production perceived internationally, affected export markets and provided more arguments for new market competitors to develop quinoa sectors in other regions of the globe (Winkel, 2011; Winkel et al., 2014). By 2015, Europe produced 7000 t, and covered $20 \%$ of the European demand for quinoa (Mercadero, 2016). The development and distribution of quinoa outside the Andean region will not stop. Regulation of international food economics to avoid unbalanced competition (Winkel et al., 2014) seems difficult to achieve (at least in the short term) due to interests involved. Therefore, the active participation of the Andean region may be the way to bring solutions to this process.

A positive aspect we can mention from the production of quinoa in other latitudes is that this grain constitutes a possibility to diversify global production systems that are centered around a reduced number of species. It also helps to diversify diets and offers the possibility to generate new plant-based food alternatives, to reduce meat production that is harming the environment. Developed countries have the global responsibility to reduce greenhouse gas emissions and become more energy efficient (European Commission, 2019). The production of meat emits equivalent greenhouse gases (GHG) to the transportation sector, and livestock production uses almost $70 \%$ of the agricultural land (Ripple et al., 2014; Machovina et al., 2015). It is the most important driver for land use change for feed, through deforestation of millions of hectares (mainly located in the global south) that comes coupled with biodiversity loss (Rojas-Downing et al., 2017; Gerber et al., 2013; Machovina et al., 2015). Diets need to change; therefore, different protein sources are necessary. Plant protein represents an option to help reducing negative impacts on the environment. Quinoa is a high quality protein grain and it constitutes a possibility to reduce the global food environmental footprint.
On the other hand, compared to the Andean region, production systems in northern continents rely on few cultivars. As a result of plant breeding, new cultivars could in the long term be adopted in the Andean countries to solve yield gaps and they could represent a risk and have implications for the Andean agro-biodiversity. Active and collaborative breeding programs based on local diversity and addressed to different markets would avoid negative impacts and take advantage of positive results to increase productivity.

\subsubsection{Ethical use of genetic resources}

How fair is it for the countries of origin of quinoa to share genetic resources with developed countries? The latter have higher capacities to develop technology to become a serious market competitor for the Andean countries. Countries traditionally producing quinoa may lose their share of the market and become dependent on newly generated cultivars to respond increasing demand. The equitable distribution of benefits derived from genetic resources use, recognition of areas of origin, seed property rights and pathways to access the diversity of genetic resources are issues that generate debate. These need more discussion for the improvement of the existing legal framework (Winkel et al., 2014; Chevarria-Lazo et al., 2015; Bazile et al., 2016a; Bazile and Baudron, 2014).

So far, the recognition of Andean populations for the conservation of quinoa can be done through minimal monetary compensations (Chevarria-Lazo et al., 2015), which mainly target conservation processes (Convention of Biological Diversity - CBD and Nagoya Protocol). Other regulations (e.g. Plant Variety Protection; PVP) protect only the last phases of innovation processes (breeding) and not the source of the genetic materials used. In addition, high costs linked to this type of intellectual property right protection do not fit in most of the cases with the research system or the reality in Andean countries. In fact, only three PVP registrations have been granted to Andean countries (UPOV, 2019). Within the International Treaty on Plant and Genetic Resources for Food and Agriculture (ITPGRFA), the Multilateral System (MS) that enables the exchange and sharing of benefits of genetic resources use does not include quinoa. This system could help to trace the source of materials used in innovation (provided that identification codes of gene banks remain the same), make agreements between stakeholders and avoid misappropriation of plant material. It would also allow the establishment of collaborative breeding programs, which could result in shared benefits from resulting cultivars. Nevertheless, the mechanisms to make this system effective are often described as ambiguous and difficult to apply. Finally, the Open Source Seed License (OSSL) is a mechanism that could allow, to some extent, the exchange of seeds, protecting them from misappropriation. However, it also does not guarantee total traceability of genetic resource use (Esquinas-Alcázar, 2005; Winkel, 2011; Chevarria-Lazo et al., 2015; Bazile et al., 2016a).

The development of new cultivars by countries outside the Andean region is possible without the application of the international framework, therefore without recognition or share of benefits with the countries that have conserved quinoa for a thousand of years. To date, 26 cultivars have been approved for registration as plant breeder rights in different periods, countries and regions outside the Andean region (most of them in Europe). The registration of materials doubled after 2013: from 1997 - 2013, 13 materials were registered and from 2014 2023, 26 (UPOV, 2019).

Andean countries need to find effective ways to keep benefiting from the global market they have conquered by getting creative in business and by using the available regulations that bring tangible benefits to farmers of their region. The revision, complementation, and harmonization of the existing legal framework may be an option for the development of equitable opportunities for the countries that have conserved the existing biodiversity of this grain (Chevarria-Lazo et al., 2015). Intellectual protection tools such as geographical indications can help to promote, conserve and protect genetic materials, production systems, culture and tradition. In Bolivia, a denomination of origin (DO) was 
recognized in 2002 at national scale. In 2014, it was recognized by the Andean community (CAN) i.e. Ecuador, Peru, Colombia and Bolivia (Royal Quinoa DO Regulatory Council, 2019). The registration under the World Intellectual Property Organization (WIPO) is in process. This type of protection can translate into higher local and regional economic revenues for farmers but not necessarily in effective conservation of diversity, practices and knowledge (Larson Guerra, 2010).

The use of other soft legal frameworks could also help in this process, as will be discussed further.

\subsection{Potential of production in the Andean region and possible strategies}

\subsubsection{The Andean region: the main world producers}

The countries with major quinoa production in Latin America are Peru, Bolivia and Ecuador with a total of 172,000 ha in 2018. In these three countries, quinoa is produced under diverse agro-ecological conditions and production systems. From traditional production systems characterized by medium (up to $10 \mathrm{ha}$ ) and small-scale plots ( $<2 \mathrm{ha}$ ) with low input technology; to extensive cultivation in the Bolivian southern highlands and in the coastal region of Peru. In general, the crop is produced under rain-fed conditions and subjected to extreme meteorological events and oscillations (e.g. El Niño \& La Niña) that affect seed yields.

Around $30-40 \%$ of quinoa produced in Peru, Bolivia and Ecuador is certified organic. Bolivia is the country that exports most organic quinoa, whereas Peru exports most conventional (Oficina Internacional del Trabajo, 2015; Instituto boliviano de Comercio Exterior, 2015; Ecuador, 2015).

\subsubsection{Diversity conservation}

The Andean region contains a great variability of areas and production systems where quinoa is produced. This represents a great potential to continue developing markets. Unique characteristics from the Andean region provide narratives for labels that increase the value of products addressed to consumers demanding authentic food. Besides, Andean countries hold an enormous genetic diversity including that of quinoa. Indeed, the region maintains most of the accessions available worldwide, however, under conditions that do not ensure their preservation. Investments are necessary to avoid losing these valuable resources and to make use of the rich biodiversity of quinoa and its wild relatives (Rojas et al., 2015). Governments should turn their attention to this asset and to the assorted array of products they can offer, both to their local population and to the rest of the world. For this, the application of results from previous research and development of new studies that lead to useful innovations are needed.

\subsubsection{Productivity}

Quinoa production in the Andean region has increased around $165,000 \mathrm{t}$ in the last 15 years (2003-2018). However, the region yield average recently attained $1 \mathrm{t} \mathrm{ha}^{-1}$ with serious observations to the sustainability of quinoa production systems. Therefore, efforts are necessary to enhance productivity in the areas of the region with low yields (e. $\mathrm{g}$ Bolivia) and revise the sustainability of intensive production systems (e.g. coast of Peru). The internal competition in the region can intensify the current implications from the international context. Important recommendations that have been highlighted in debates about quinoa sustainability should be considered.

Andean countries should take advantage of the research and technology already developed in the region. Collaborative projects to solve yield gaps and enhance sustainable crop management are necessary. Important areas of focus that can be mentioned are soil erosion, salinity, fertility and territory management in the arid areas of quinoa production (Bolivian southern highlands); integrated pest and disease management in the intensive areas of production (coastal regions of Peru). In all countries: development of mechanized systems adequate for each region; development of organic integrated crop management; plant breeding and production of certified seed from local varieties. In addition, sustainable conventional cropping systems can also be applied in order to maintain the diverse market demand. As suggested by other studies, two models could be feasible for quinoa in the Andean region: a commodity model and a food sovereignty model (Avitabile, 2015).

\subsubsection{Markets}

Organic quinoa represents around $30 \%$ of the quinoa produced in the main producing countries of the Andean region. The production of organic quinoa is still challenging in the new countries producing this grain where Chenopodiaceae weeds pests and diseases still represent a problem not yet solved. Until this sector is developed, the Andean countries still maintain this share of the global market.

More efforts are needed to add value to produced quinoa. In 2000, Bolivia (by then first world producer) exported only $3 \%$ as processed goods (Gandarillas Terceros, 2011). Genetic resources can be used according to their characteristics and properties (e.g. using quinoa of small grain size for industry, exporting "Real" quinoa with attractive, large grain sizes and colors, identifying the specificity of quinoa varieties for industrialization). Andean countries should consider the recovery of traditional ways of consumption using existing information of projects, recovering these and using it in creative ways for promotion (e.g. food fairs, tv shows, social media, among others). Synergies can be created between tradition, science, technology and commercialization. Scientific methods could be used to help to uncover the reasoning behind traditional production techniques, and products can be developed and industrialized with technology (e.g. traditional recipes). This will result in a product with tradition as an extra added value that can be promoted in local and external markets. To ensure a better distribution of income it is important to connect consumers directly to farmers and associations.

Other strategies to consider include the development of new, specialty and niche markets. To protect and recognize the origin of genetic resources, the Andean region should take advantage of different schemes of geographical indication. Efforts should continue to get the Real DO to the rest of the world and other schemes to reach niche markets should be pursued. Considering that the climate conditions in the area where this type of quinoa is cultivated are extreme and difficult for the local farmers, this would be a fair recognition of the efforts that conserving and producing this quinoa represents. Payments for agrobiodiversity conservation services (PACS) cases have been analyzed in the Andean region and a mixture of incentive instruments have been recommended for broad conservation strategies (Drucker et al., 2015). To keep the different certifications obtained, farmers should also keep a serious commitment to maintain sustainable production systems. Collective brands (formed by different producer associations) and strengthened by the public sector and other partners represent other opportunities to develop the value chain, differentiate quinoa and increase prices (Duran y Lalaguna and Dorodnykh, 2018). Farmer associations, institutions, governments and external cooperation should address these efforts. Other examples of appellation schemes that could be used are products with traditional specialty guarantee. Soft regulations such as the Globally Important Agricultural Heritage Systems (GIAHS) and the cultural landscapes protection systems can be strategies to conserve biodiversity, production systems and identity (Chevarria-Lazo et al., 2015).

Farmers can still benefit from consumers willing to pay for exclusive products that do not come from conventional farming systems. The Andean region is full of traditions, stories and diverse characteristics that make its products unique and appealing for people eager to compensate farmers' efforts, in order to eat healthy, distinct products. This market strategy represents a way ahead than just focusing on quinoa grain traits.

\subsubsection{Diversification and collaboration}

Diversifying production systems that include other underutilized species (e.g. Andean lupin, tubers, camelids, medicinal plants, among 
others) would also diversify the sources of income. Other activities such as agro-ecotourism add value to products; examples can be found where quinoa is part of the agro-touristic offer in Peru (Barbieri et al., 2020) or rural agro-tourism packages concentrated only in quinoa and related traditions such as in Bolivia (Muñoz and Prado, 2019). The consideration of the socio-economic dynamics and the participation and consensus of local stakeholders is fundamental. More would be achieved at the local level if efforts are unified between different sectors i.e. farmer associations, universities, private sector, government and relevant institutions.

Andean countries have to find effective and innovative ways to keep promoting and diversifying its domestic consumption at different levels. By easing the processes for business creation, access to markets and national programs (e.g. school meals); recovery of traditional ways of consumption; promotion of innovative products that include quinoa as an ingredient. To achieve this we recommend more research and innovation towards development and diversification of products.

The region should propose projects that unify efforts south - south and north - south where farmers are included in order to enhance research, technology and industrialization. All projects, actions and activities should ensure a fair and concerted access to resources (genetic, knowledge, economic) to get mutual and equilibrated benefits for all parties.

\section{Conclusions}

The global distribution of quinoa has changed significantly over the last century. From being produced in six countries, now this grain is present in more than 120 countries around the world. This uptake was driven by the increasing interest, market development, research and promotion. This new scenario brings new competitors for the Andean region where quinoa is produced in both traditional and intensive production systems. Some of the main challenges are unstable yields, low technology, fragile ecosystems and unclear regulations surrounding the sharing of benefits from the conservation of Andean genetic resources. The interest for developing quinoa outside its area of origin is not going to stop. In fact, quinoa represents a good crop for global food security and an opportunity for producing high quality protein with little impact to the environment. In order to remain in the global market without losing its diversity, the Andean region will need to actively join in this process. Innovative alliances at different scales will be needed. Local alliances are important to continue optimizing yields, the production system, the whole value chain, as well as the connection between farmers and consumers. Regional alliances can be used to share knowledge, technology and market strategies. These can strengthen the region and ensure that livelihoods continue improving in a sustainable way. Finally, international collaboration will be positive if equitable distribution of benefits can be ensured, under clear and applicable agreements, securing genetic and cultural resources.

\section{Declaration of competing interest}

The authors declare that they have no known competing financial interests or personal relationships that could have appeared to influence the work reported in this paper.

\section{Acknowledgements}

The authors wish to thank Nes Odone and Lucy Owens for the valuable help provided with the language revision and helpful comments on this manuscript.

The authors wish to recognize the memory of Dr. Antonio Gandarillas and from all great quinoa researchers from the Andean region. We also acknowledge to Fundación PROINPA for the trust and support during this research.

This research was funded by DANIDA (Danish International
Development Agency) under the project ANDESCROP $\mathrm{N}^{\circ}$ 104.Dan 8-1203.

\section{References}

Adolf, V.I., Jacobsen, S.-E., Shabala, S., 2013. Salt tolerance mechanisms in quinoa (Chenopodium quinoa Willd.). Environ. Exp. Bot. 92, 43-54. https://doi.org/ 10.1016/j.envexpbot.2012.07.004.

Alandia, G., Blajos, J., Rojas, W., 2011a. Chapter 6: economic aspects of quinoa throughout the world. In: FAO - Regional Office for the Americas and the Caribbean (Ed) Quinoa: an Ancient Crop to Contribute to World Food Security. Santiago de Chile, pp. 37-42. http://www.fao.org/3/aq287e/aq287e.pdf.

Alandia, G., Blajos, J., Rojas, W., 2011b. Chapter 7: expansion of quinoa cultivation to countries outside the Andean region. In: Quinoa: An Ancient Crop to Contribute to World Food Security, Food and Agriculture Organization of the United Nations (Ed). FAO - Regional Office for the Americas and the Caribbean, pp. 43-45. Santiago de Chile. http://www.fao.org/3/aq287e/aq287e.pdf.

Albert, V., 2017. King quinoa: the development of the modern export market and its implications for the Andean people. Grad. J. Food Stud. 4, 1-10.

Aroni, G., 2008. Recuperación de suelos para una producción sostenible de quinua en el Altiplano Sur. Revista Habitat 75, 50-53.

Astudillo, D., Aroni, G., 2012. Livelihoods of quinoa producers in southern Bolivia. In: Giuliani, A., Hintermann, F., Rojas, W., Padulosi, S. (Eds.), Biodiversity of Andean Grains: Balancing Market Potential and Sustainable Livelihoods. Bioversity International, Rome, Italy, pp. 129-133. https://www.bioversityinternational.org/fi leadmin/user_upload/online_library/publications/pdfs/1635.pdf.

Avitabile, E., 2015. Value Chain Analysis, Social Impact and Food Security. The Case of Quinoa in Bolivia. Ph. D. thesis. Universit degli studi Roma Tre. https://arcadia.sba. uniroma3.it/bitstream/2307/5235/1/Tesi_Avitabile.pdf.

Baer, K., 1839. ПредлоЖение о разведении квинои в северных областях Российской иМперии, 1839 год [Электронный ресурс] - in English Baer, К. 1839. Proposal for breeding quinoa in the northern regions of the Russian Empire, 1839 [Electronic resource]//AgroXXI. Access mode. http://www.agroxxi.ru. Saint Petersburg, 25 pp.

Barbieri, C., Sotomayor, S., Gil, S., 2020. Sustainable tourism practices in indigenous communities: the case of the Peruvian Andes. Tourism Plann. Dev. 17 (2), 207-224. https://doi.org/10.1080/21568316.2019.1597760.

Bazile, D., Baudron, F., 2014. Dinámica de expansión mundial del cultivo de la quinua respecto a su alta biodiversidad. In: Bazile, D., et al. (Eds.), Estado del arte de la quinua en el mundo en 2013, pp. 49-64. FAO y CIRAD: Santiago de Chile; Montpellier, Francia. http://www.fao.org/3/a-i4042e.pdf.

Bazile, D., Jacobsen, S.-E., Verniau, A., 2016a. The global expansion of quinoa: trends and limits. Front. Plant Sci. 7, 622. https://doi.org/10.3389/fpls.2016.00622.

Bazile, D., Pulvento, C., Verniau, A., Al-Nusairi, M.S., Ba, D., Breidy, J., Hassan, L., Mohammed, M.I., Mambetov, O., Otambekova, M., Sepahvand, N.A., 2016b. Worldwide evaluations of quinoa: preliminary results from post international year of quinoa FAO projects in nine countries. Front. Plant Sci. 7, 850. https://doi.org/ 10.3389/fpls.2016.00850.

Bedoya-Perales, N.S., Pumi, G., Mujica, A., et al., 2018a. Quinoa expansion in Peru and its implications for land use management. Sustainability 10 (2), 532. https://doi. org/10.3390/su10020532.

Bedoya-Perales, N.S., Pumi, G., Talamini, E., Padula, A.D., 2018b. The quinoa boom in Peru: will land competition threaten sustainability in one of the cradles of agriculture? Land Use Pol. 79, 475-480. https://doi.org/10.1016/j. landusepol.2018.08.039.

Bhargava, A., Ohri, D., 2014. Chapter 6.2. Quinoa in the Indian subcontinent. In: Bazile, D., Bertero, D., Nieto, C. (Eds.), State of the Art Report on Quinoa Around the World in 2013. FAO and CIRAD, Rome, pp. 511-523. http://www.fao.org/3/a-i 4042e.pdf.

Bruno, M.C., 2006. Chapter 4: A morphological approach to documenting the domestication of Chenopodium in the Andes. In: Zeder, Melinda A., Bradley, Daniel G., Emshwiller, Eve, Smith, Bruce D. (Eds.), Documenting Domestication: New Genetic and Archaeological Paradigms. University of California Press, London, England, pp. 32-45.

CBI Market Information Database, 2017. Exporting quinoa to Europe. In: CBI Market Information: Grain and Pulses - Quinoa Seeds, vol. 18.

Chevarria-Lazo, M., Bazile, D., Dessauw, D., Louafi, S., Trommetter, M., Hocdé, H., 2015. Quinoa and the exchange of genetic resources: improving the regulation systems. In: al BDe (Ed.), Estado del arte de la quinua en el mundo en 2013. FAO, CIRAD: Santiago de Chile, Montpellier, pp. 95-123. http://www.fao.org/3/a-i4042e.pdf.

Drucker, A.G., Narloch, U., Pascual, U., Soto, J.L., Pinto, M., Midler, E., Valdivia, E., Rojas, J., 2015. Domestication of Payments for Ecosystem Services: New Evidence from the Andes. CAPRi Working Paper No. 118. Washington, D.C.: International Food Policy Research Institute. https://doi.org/10.2499/CAPRiWP118.

Duran y Lalaguna, P., Dorodnykh, E., 2018. The role of private-public partnerships in the implementation of sustainable development goals: experience from the SDG fund. In: Handbook of Sustainability Science and Research. Springer, Cham, pp. 969-982. https://doi.org/10.1007/978-3-319-63007-6_60.

Ecuador, P., 2015. Análisis sectorial: quinua 2015. PRO ECUADOR Instituto de Promoción de Exportaciones e Inversiones (ed). PRO ECUADOR: guayaquil, Quito, Ecuador. http://quinua.pe/wp-content/uploads/2016/04/PROEC_AS2015_Q UINUA.pdf, 18.

Esquinas-Alcázar, J., 2005. Protecting crop genetic diversity for food security: political, ethical and technical challenges. Nat. Rev. Genet. 6, 946. https://doi.org/10.1038/ nrg1729. 
ESRI, 2011. ArcGIS Desktop: Release 10. Environmental Systems Research Institute, Inc., Redlands, California.

European Commission, 2017. Quinoa, amaranth: ancient grains hold promising future: Brussels. https://ec.europa.eu/research/infocentre/article_en.cfm?\&art id $=45756 \&$ caller $=$ other.

European Commission, 2019. Effort sharing: member States' emission targets. Accessed 12/04 2019. https://ec.europa.eu/clima/policies/effort_en.

FAO, 2011. Resolution. In: Quinoa: An ancient crop to contribute with world food security, FAO - Regional Office for the Americas and the Caribbean (ed). Food and Agriculture Organization of the United Nations: Santiago de Chile; iii. http://www.fao.org/3/a q287e/aq287e.pdf.

FAO, 2013. Calendario de eventos. Santiago de Chile. http://www.fao.org/quinoa -2013/activities/calendar-events/en/.

FAO, 2014. Assessment of the international year of quinoa 2013. In: Hundred and FortyNinth Session - CL 149/10. FAO, Rome. http://www.fao.org/3/mk172E/mk172E. pdf.

FAO, 2019. FAOSTAT. In: Data - Crops: Quinoa for Bolivia, Yield, Area Harvested, Production Quantity for Ecuador and Peru for 1961 - 2017. Food and Agriculture Organization of the United Nations. http://www.fao.org/faostat/en/\#data/QC.

FAO and Bioversity international, 2012. In: Celebrando el Año Internacional de la Quinua: Un futuro sembrado hace miles de años. FAO - Regional Office for the Americas and the Caribbean (ed): Santiago de Chile. http://www.fao.org/fileadmin/ templates/aiq2013/res/es/nota_conceptual.pdf.

Fleming, J.E., Galwey, N.W., 1995. Quinoa (Chenopodium quinoa). In: Williams, J.T. (Ed.), Cereals and Pseudocereals, vol. 1. Chapman and Hall, London, pp. 3-83 (Underutilised crop series, vol. 2).

Gallardo, M., Gonzalez, J., Ponessa, G., 1997. Morfologia del fruto y semilla de Chenopodium quinoa Willd ("quinoa") Chenopodiaceae. Fruit and seed morphology of Chenopodium quinoa Willd ("quinoa") Chenopodiaceae. Lilloa 39, 71-80.

Galwey, N., 1993. The potential of quinoa as a multi-purpose crop for agricultural diversification: a review. Ind. Crop. Prod. 1, 101-106. https://doi.org/10.1016/ 0926-6690(92)90006-H.

Gandarillas, A., Wilfredo, R., Alejandro, B., Norka, O., 2014. La quinua en Bolivia: perspectiva de la Fundación PROINPA. In: Bazile, D., et al. (Eds.), Estado del arte de la quinua en el mundo en 2013, FAO and CIRAD: Santiago de Chile - Montpellier, pp. 410-431. Francia. http://www.fao.org/3/a-i4042e.pdf.

Gandarillas Terceros, M.A., 2011. The Quinoa Industry: opportunities and constraints to increase value adding activities in Bolivia. In: Department of Social Sciences, vol. 63. Wageningen University \& Research Center, Wageningen. https://edepot.wur. $\mathrm{nl} / 187886$.

Garcia, M., Condori, B., Castillo, C.D., 2015. Agroecological and agronomic cultural practices of quinoa in south America. Quinoa: Improv. Sustain. Prod. 25-46. https:// doi.org/10.1002/9781118628041.ch3.

Gerber, P.J., Steinfeld, H., Henderson, B., Mottet, A., Opio, C., Dijkman, J., Falcucci, A., Tempio, G., 2013. Tackling climate change through livestock: a global assessment of emissions and mitigation opportunities. Food and Agriculture Organization of the United Nations (FAO). http://www.fao.org/3/a-i3437e.pdf.

Giuliani, A., 2012. Conclusions. In: Giuliani, A., Hintermann, F., Rojas, W., Padulosi, S (Eds.), Biodiversity of Andean Grains: Balancing Market Potential and Sustainable Livelihoods. Bioversity International, Rome, Italy, pp. 189-197. https://www.bi oversityinternational.org/fileadmin/user_upload/online_library/publications/pdfs /1635.pdf.

Gonzáles, J.-A., Eisa, S.S., Hussin, S.A.E.S., Prado, F.-E., 2015. Chapter 1: quinoa: an incan crop to face global changes in agriculture. In: Murphy, K., Matanguihan, J. (Eds.), Quinoa: Improvement and Sustainable Production. Wiley Blackwell, New Jersey, pp. 211-226. https://doi.org/10.1002/9781118628041.ch12.

Gordillo-Bastidas, E., Díaz-Rizzolo, D., Roura, E., Massanés, T., Gomis, R., 2016. Quinoa (Chenopodium quinoa Willd), from nutritional value to potential health benefits: an integrative review. J. Nutr. Food Sci. 6, 497. https://doi.org/10.4172/21559600.1000497

Instituto boliviano de Comercio Exterior, 2015. Bolivia: productos Alimenticios con Potential Exportador. Comer. Exter. 230, 4. https://ibce.org.bo/images/publicacion es/ce-230-Bolivia-Productos-Alimenticios-Potencial-Exportador.pdf.

Instituto Nacional de Estadística, 2019. Estadísticas por actividad económica. In: Bolivia: Producción por año agrícola según cultivos - Producción, rendimiento, superficie cultivada. https://www.ine.gob.bo/index.php/estadisticas-por-actividad-ec onomica/industria-manufacturera-y-comercio-4.

International Trade Centre, 2019. List of exporters for the selected product - product: 100850 Quinoa "Chenopodium quinoa". In: Trade Map: Trade Statistics for International Business Development. International Trade Centre. https://www.tra demap.org/Country_SelProduct_TS.aspx?nvpm $=1 \% 7 \mathrm{c} \% 7 \mathrm{c} \% 7 \mathrm{c} \% 7 \mathrm{c} \% 7 \mathrm{c} 100850 \% 7 \mathrm{c}$ $\% 7 c 07 c 6 \% 7 c 1 \% 7 c 1 \% 7 c 2 \% 7 c 2 \% 7 c 1 \% 7 c 2 \% 7 c 1 \% 7 c 1$.

Jacobsen, S.-E., 2003. The worldwide potential for quinoa (Chenopodium quinoa Willd.). Food Rev. Int. 19, 167-177. https://doi.org/10.1081/FRI-120018883.

Jacobsen, S.E., 2011. The situation for quinoa and its production in southern Bolivia: from economic success to environmental disaster. J. Agron. Crop Sci. 197, 390-399. https://doi.org/10.1111/j.1439-037X.2011.00475.x.

Jacobsen, S.E., 2012. What is Wrong With the Sustainability of Quinoa Production in Southern Bolivia-A Reply to Winkel et al.(2012). J. Agron. Crop Sci. 198 (4), 320-323. https://doi.org/10.1111/j.1439-037X.2012.00511.x.

Jacobsen, S.-E., 2014. Adaptación y posibilidades para la quinua en las latitudes septentrionales de Europa. In: Bazile, D., et al. (Eds.), Estado del arte de la quinua en el mundo en 2013, pp. 519-533. FAO: Santiago de Chile y CIRAD: Montpellier. http ://www.fao.org/3/a-i4042e.pdf.

Jacobsen, S.E., Monteros, C., Christiansen, J., Bravo, L., Corcuera, L., Mujica, A., 2005. Plant responses of quinoa (Chenopodium quinoa Willd.) to frost at various phenological stages. Eur. J. Agron. 22, 131-139. https://doi.org/10.1016/j. eja.2004.01.003.

James, L.E.A., 2009. Quinoa (Chenopodium quinoa Willd.): composition, chemistry, nutritional, and functional properties. Adv. Food Nutr. Res. 58, 1-31. https://doi. org/10.1016/S1043-4526(09)58001-1.

Jarvis, D.E., Ho, Y.S., Lightfoot, D.J., Schmöckel, S.M., Li, B., Borm, T.J.A., Ohyanagi, H., Mineta, K., Michell, C.T., Saber, N., Kharbatia, N.M., Rupper, R.R., Sharp, A.R., Dally, N., Boughton, B.A., Woo, Y.H., Gao, G., Schijlen, E.G.W.M., Guo, X., Momin, A.A., Negrão, S., Al-Babili, S., Gehring, C., Roessner, U., Jung, C., Murphy, K., Arold, S.T., Gojobori, T., Linden, Cgvd, van Loo, E.N., Jellen, E.N., Maughan, P.J., Tester, M., 2017. The Genome of Chenopodium Quinoa. Nature advance online publication, pp. 1-6. https://doi.org/10.1038/nature21370. http://www.nature.com/nature/journal/vaop/ncurrent/abs/nature21370. html\#supplementary-information.

Jellen, E., 2013. Botánica, filogenia y evolución. In: Bazile, D., Bertero, D., Nieto, C. (Eds.), Estado del arte de la quinua en el mundo en 2013, pp. 12-25. FAO y CIRAD: Santiago de Chile, Chile - Montpellier, Francia. http://www.fao.org/3/a-i4042e.pdf.

Jensen, C., Jacobsen, S.-E., Andersen, M.N., Nunez, N., Andersen, S., Rasmussen, L., Mogensen, V., 2000. Leaf gas exchange and water relation characteristics of field quinoa (Chenopodium quinoa Willd.) during soil drying. Eur. J. Agron. 13, 11-25 https://doi.org/10.1016/S1161-0301(00)00055-1.

Keoke, E.D., Porterfield, K.M., 2009. Quinoa (Chenopodium quinoa, chesiya mama). In: Encyclopedia of American Indian Contributions to the World: 15,000 Years of Inventions and Innovations. Infobase Publishing. Checkmark Books, New York, United States of America, p. 222.

Kiel University, 2018. Growing quinoa in Europe. In: Research news (Ed.), Plant Breeding Institute University of Kiel. https://www.uni-kiel.de/en/research /details/news/growing-quinoa-in-europe/\#.

Laguna, P., 2011. Mallas y flujos: acción colectiva, cambio social, quinua y desarrollo regional indígena en los Andes Bolivianos. In: Department of Rural Development Sociology. Wageningen University, Wageningen, p. 516. https://edepot.wur. $\mathrm{nl} / 188049$.

Laguna, P., Cáceres, Z., Carimetrand, A., 2006. Del Altiplano Sur boliviano hasta el mercado global: coordinación, regulación y calidad en el mercado en la cadena de valor de la quinua. In: Agroindustria Rural y Territorio (tomo1): Los desafíos de los sistemas agroalimentarios localizados. Universidad Autónoma del Estado de México, pp. 375-407. https://library.wur.nl/WebQuery/wurpubs/fulltext/185059.

Larson Guerra, J., 2010. Geographical indications, in situ conservation and traditional knowledge. ICTSD Pol. Brief 3, 16. https://www.ictsd.org/sites/default/files/rese rch/2011/12/geographical-indications-in-situ-conservation-and-traditional-know ledge.pdf.

López-Marqués, Rosa, Nørrevang, Anton F., Peter, Ache, Moog, Max, Visintainer, Davide, Wendt, Toni, Østerberg, Jeppe T., Dockter, Christoph, Jørgensen, Morten E., Torres Salvador, Andrés, Hedrich, Rainer, Gao, Caixia, Jacobsen, Sven-Erik, Shabala, Sergey, Palmgren, Michael, 2020. Prospects for the accelerated improvement of the resilient crop quinoa. J. Exp. Bot. 15. https://doi.org/10.1093/ jxb/eraa285.

Loskutov, I.G., 1999. Vavilov and His Institute. A History of the World Collection of Plant Genetic Resources in Russia. International Plant Genetic Resources Institute, Rome, Italy, 195pp.

Machovina, B., Feeley, K.J., Ripple, W.J., 2015. Biodiversity conservation: the key is reducing meat consumption. Sci. Total Environ. 536, 419-431. https://doi.org/ 10.1016/j.scitotenv.2015.07.022.

Maughan, P.J., Bonifacio, A., Coleman, C.E., Jellen, E.N., Stevens, M.R., Fairbanks, D.J., 2007. Chapter 9: quinoa (Chenopodium quinoa). In: Pulses, Sugar and Tuber Crops. Springer, pp. 147-158. https://doi.org/10.1007/978-3-540-34516-9_9.

Mercadero, 2016. Figures for European consumption of quinoa revised. In: Mercadero (Ed.), Mercadero Local Dreams, Global Business: Quinoa Market Analysis, Mercadero: Wageningen - The Netherlands. https://www.mercadero.nl/figures-foreuropean-consumption-of-quinoa-revised/.

Ministerio de Agricultura y Ganadería - Ecuador, 2017. Quinua. In: Boletín Situacional,. Sistema de Información Pública Agropecuaria - SIPA, vol. 6. https://fliphtml5.com/ ijia/jsjc.

Ministerio de Agricultura y Ganadería - Ecuador, 2019. Cifras agroproductivas principales cultivos - 2018. Sistema de Información pública agropecuaria. https ://www.ecuadorencifras.gob.ec/estadisticas-agropecuarias-2/.

Ministerio de Agricultura y Riego - Perú, 2018. Manejo Agronómico - prácticas de conservación de suelos, producción, comercialización y perspectivas de Granos Andinos. Dirección General de Políticas Agrarias - DGPA \& Dirección de Estudios Económicos e Información Agraria. Lima; 88. http://agroaldia.minagri.gob.pe/bi blioteca/download/pdf/tematicas/f-taxonomia_plantas/f01-cultivo/2019/manejo granos andinos19.pdf.

Muñoz, D.F., Prado, C.D., 2019. El Agroturismo comunitario ancestral de la quinua en Bolivia. In: Libro de Resúmenes. VII Congreso Mundial de la Quinua y Otros Granos Andinos. Ministerio de Agricultura, INDAP, Pontífica Universidad Católica de Chile. Santiago de Chile, Chile.

Núñez de Arco, S., 2015. Chapter 12: quinoa's calling. In: Murphy, K., Matanguihan, J. (Eds.), Quinoa: Improvement and Sustainable Production. Wiley Blackwell, New Jersey, pp. 211-226. https://doi.org/10.1002/9781118628041.ch12.

Oficina Internacional del Trabajo, 2015. Análisis de la cadena de valor en el sector de la quinua en Perú: aprovechando las ganancias de un mercado creciente a favor de los pobres: Ginebra. https://www.ilo.org/wcmsp5/groups/public/_ed_emp/—emp _ent/_ifp_seed/documents/publication/wcms_706800.pdf.

Oyoo, M.E., Khaemba, J., Githiri, S.M., Ayiecho, P.O., 2014. Capítulo 6.32: producción y utilización de la quinua (Chenopodium quinoa Willd) más allá de sus tradicionales zonas de cultivo: un caso de Kenia. In: Bazile, D., Bertero, D., Nieto, C. (Eds.), Estado 
del Arte de la Quinua en el mundo en 2013, pp. 647-664. FAO - CIRAD: Santiago de Chile; Montpellier, Francia. http://www.fao.org/3/a-i4042e.pdf.

Peralta, E., Mazón, N., 2014. La quinua en Ecuador. In: Estado del arte de la quinua en el mundo en 2013. FAO and CIRAD: Santiago de Chile - Montpellier, Francia, pp. 462-476. http://www.fao.org/3/a-i4042e.pdf.

Peterson, A.J., Murphy, K.M., 2014. Capítulo 6.41: La quinua en los Estados Unidos y Canadá. In: Bazile, D., Bertero, D., Nieto, C. (Eds.), Estado del arte de la quinua en el mundo en 2013, pp. 665-680. FAO - CIRAD: Santiago de Chile; Montpellier, Francia. http://www.fao.org/3/a-i4042e.pdf.

Piva, G., Brasse, C., Mehinagic, E., 2014. Quinua d'Anjou: comienzo del sector de quinua Francesa. In: al DBe (Ed.), Estado del arte de la quinua en el mundo en 2013, pp. 534-541. FAO: Santiago de Chile y CIRAD: Montpellier. http://www.fao. org/3/a-i4042e.pdf.

Planella, M.T., López, M.L., Bruno, M.C., 2014. Capítulo 1.3: La domesticación y distribución prehistórica. In: Bazile, D., Bertero, D., Nieto, C. (Eds.), Estado del arte de la quinua en el mundo en 2013, pp. 33-48. FAO y CIRAD: Santiago de Chile y Montpellier, Francia. http://www.fao.org/3/a-i4042e.pdf.

Rea, J., 1992. Los congresos sobre cultivos Andinos a través del tiempo y su evolución. In: Morales, D., Vacher, J. (Eds.), Actas del VII Congreso Internacional sobre cultivos Andinos, La Paz Bolivia 4 al 8 de Febrero 1991. IBTA, ORSTOM, CIID-Canada, La Paz, p. 423. https://horizon.documentation.ird.fr/exl-doc/pleins_textes/divers0911/38551.pdf.

Repo-Carrasco, R., Espinoza, C., Jacobsen, S., 2003. Nutritional value and use of the Andean crops quinoa (Chenopodium quinoa) and kaniwa (Chenopodium pallidicaule). Food Rev. Int. 19, 179-189. https://doi.org/10.1081/FRI-120018884.

Reynolds, J.F., Huber-Sanwald, E., Herrick, J.E., 2008. La sustentabilidad de la producción de quinua en el Altiplano Sur de Bolivia: aplicación del Paradigma de Desarrollo de Zonas Secas. Revista Habitat 75, 10-15.

Ripple J., William, Smith, Pete, Haberl, Helmut, Montzka A., Stephen, McAlpine, Clive, Boucher H., Douglas, 2014. Ruminants, climate change and climate policy. Nat. Clim. Change 4 (1), 1-5.

Risi, J., Galwey, N., 1984. The Chenopodium grains of the Andes: inca crops for modern agriculture. Adv. Appl. Biol. 10, 145-216.

Rojas, W., Alandia, G., Irigoyen, J., Blajos, J., 2011. Quinoa: an ancient crop to contribute to world food security. Food and Agriculture Organization of the United Nations: santiago de Chile, Chile. http://www.fao.org/3/aq287e/aq287e.pdf.

Rojas, W., Pinto, M., Alanoca, C., Gómez Pando, L., León-Lobos, P., Alercia, A., Diulgheroff, S., Padulosi, S., Bazile, D., 2015. Quinoa genetic resources and ex situ conservation. In: Bazile, D., et al. (Eds.), State of the Art Report on Quinoa Around the World in 2013. FAO \& CIRAD, Rome, pp. 56-82. http://www.fao.org/3/a-i 4042e.pdf.

Rojas-Downing, M.M., Nejadhashemi, A.P., Harrigan, T., Woznicki, S.A., 2017. Climate change and livestock: impacts, adaptation, and mitigation. Clim. Risk Manag. 16, 145-163. https://doi.org/10.1016/j.crm.2017.02.001.

Royal Quinoa DO Regulatory Council, 2019. Denominación de origen (DO) de la quinua real del Altiplano Sur de Bolivia. DO - Background. http://www.doquinoareal. com/background/.

Ruales, J., Nair, B., 1992. Nutritional quality of the protein in quinoa (Chenopodium quinoa, Willd) seeds. Plant Foods Hum. Nutr. 42, 1-11.

Spehar, C.R., de Souza, PIdM., 1993. Adaptação da quinoa (Chenopodium quinoa Willd.) ao cultivo nos cerrados do Planalto Central: resultados preliminares. Pesqui. Agropecuária Bras. 28, 635-639.
Spehar, C.R., Santos, RdB., Jacobsen, S.-E., 1998. Andean grain crop introduction to the Brazilian Savannah. In: Proceedings of the International Conference on Sustainable Agriculture on Tropical and Subtropical Highlands with Special Reference to Latin America. Embrapa-Solos/INT/UFRJ/Karlsruhe Universitat, Rio de Janeiro, RJ.

Tapia, M., 2014. El largo camino de la quinoa: ¿Quiénes escribieron su historia? In: Bazile, D., et al. (Eds.), Estado del arte la quinua en el mundo en 2013, pp. 3-10. FAO y CIRAD: Santiago de Chile y Montpellier. http://www.fao.org/3/a-i4042e.pdf.

Tapia, M., Gandarillas, H., Alandia, S., Cardozo, A., Mujica, A., Ortiz, R., Otazu, V., Rea, J., Salas, B., Zanabria, E., 1979. In: Mario, T., Gandarillas, H., Alandia, S., Cardozo, A., Mujica, A. (Eds.), Quinua y Kañiwa cultivos Andinos, 40. CIID; IICA, Bogotá, Colombia, p. 228. https://idl-bnc-idrc.dspacedirect.org/handle/10625/411 8.

Tester, M., Langridge, P., 2010. Breeding technologies to increase crop production in a changing world. Science 327, 818-822. https://doi.org/10.1126/science.1183700.

The Carlsberg Foundation, 2019. Raising qunoa: an orphan crop that is healthy and ready for a changing climate. In: Newsletter. The Carlsberg Foundation. htt ps://www.carlsbergfondet.dk/en/Forskningsaktiviteter/Bevillingsstatistik/Bevilling soversigt/CF18_1113_Michael-Broberg-Palmgren.

Todo sobre la Quinua, 2019. Precios de la Quinua Real en Challapata - Oruro, Bolivia. www.laquinua.blogspot.com.

UPOV, 2019. PLUTO: plant variety database - Chenopodium quinoa. UPOV. http s://www.upov.int/pluto/data/current.pdf, 2.

UPOV-ARS, 2019. Breeding and agronomy of quinoa for organic farming systems. In: Agricultural Research Service. Sustainable Agricultural Systems Laboratory, Beltsville, MD. https://www.ars.usda.gov/research/project/?accnNo=433964.

Vassas, A., 2008. El auge de la quinua: cambios y perspectivas desde una visión social. Revista Habitat 75, 31-35.

Vassas, A., Vieira P, M., 2010. La production de quinoa dans l'altiplano sud de la Bolivie: entre crises et innovations. In: ISDA 2010, vol. 12. Montpellier. https://hal.archives -ouvertes.fr/hal-00521945/document.

Winkel, T., 2011. Para durar, cambiemos: paradojas y lecciones del éxito de la quinua. Informe final del proyecto de investigación EQUECO. Emergencia de la quinua en el comercio mundial: consecuencias parar la sostenibilidad solcial y agrícola en el altiplano boliviano. In: ANR (Ed.), Proyecto ANR-06-PADD-011, Cooperación FrancoBoliviana, p. 92. Agencie Nationale de la Recherche: Montpellier, Francia. https ://horizon.documentation.ird.fr/exl-doc/pleins_textes/divers12-08/010052575.pdf.

Winkel, T., Bertero, H., Bommel, P., Bourliaud, J., Chevarría Lazo, M., Cortes, G., Gasselin, P., Geerts, S., Joffre, R., Léger, F., 2012. The sustainability of quinoa production in southern Bolivia: from misrepresentations to questionable solutions. Comments on jacobsen (2011, J. Agron. Crop sci. 197: 390-399). J. Agron. Crop Sci. https://doi.org/10.1111/j.1439-037X.2012.00506.x.

Winkel, T., Álvarez-Flores, R., Bertero, D., Cruz, P., del Castillo, C., Joffre, R., Parada, S. P., Tonacca, L.S., 2014. Calling for a reappraisal of the impact of quinoa expansion on agricultural sustainability in the Andean highlands. IDESIA 32, 95-100. https:// scielo.conicyt.cl/pdf/idesia/v32n4/art12.pdf.

Xiu-shi, Y., Pei-you, Q., Hui-min, G., Gui-xing, R., 2019. Quinoa industry development in China. Cienc. Investig. Agrar. 46, 208-219. https://doi.org/10.7764/rcia. v46i2.2157.

Zandstra, H., 1997. Quinoa (Chenopodium quinoa) A healthy andean cereal. In: Stølen, O., Bruhn, K., Pithan, K., J, H. (Eds.), Crop Development for Cool and Wet Regions in Europe: Small Grain and Pseudo-cereals Workshop, pp. 1-5. European Commisssion European cooperation in the field of scientific and technical research: Italy. 